\title{
靱皮繊維の生化学パルプ化機構について
}

工業技術院四国工業技術試験所 小林 良生，田辺 寛之

\section{Mechanistic Investigations on Biochemical Pulping of Bast Fibers}

\author{
Yoshinari Kobayashi and Hiroyuki Tanabe \\ Government Industrial Research Institute, Shikoku
}

Mechanistic investigations on biochemical pulping of bast fibers were overviewed from viewpoints of biochemical properties of enzymes causing maceration and solubilized components.

The pulping using pectinolytic enzymes secreted by Erwinia carotovora was found to proceed by maceration as the result of concerted reaction of endo-pectate lyase (endo-PATE) and endo -pectin lyase (endo-PNTE). The endo-PATE was composed of 4 kinds, or sometime 2 kinds, of pI -isozyme, depending on the strains used. The optimal constitution ratio of endo-PATE to endo -PNTE was approximately $30: 1$.

Both in alkaline presoaking and enzymatic pulping, lignin-carbohydrate complexes with molecular weight of 20,000-25,000 were found to be eluted.

As to aggregation between pectic substance and LCC, endo-PATE yielded the elution of LCC rich in L-arabinose and D-galactose, while endo-PNTE produced that mainly composed of D-xylose in the pulping of mitsumata (Edgeworthia papyrifera Sieb. et Zucc.). This result was commented in relation with biosynthesis process of hemicellulose.

Keywords : Bast fibers, Biochemical pulping, Mechanism, Maceration, Pectinolytic enzymes, Erwinia carotovora

\section{1.はじめに}

植物原料から生化学的反応で繊維を解繊・抽出する プロセスをバイオケミカルパルプ化, 又は生化学パル プ化 (biochemical pulping) と呼び，これには微生物 の増殖に伴なって起るバイオロジカルパルプ化 (biological pulping) と酵素によるパルプ化 (enzymatic pulping）とが含まれる ${ }^{12)}$ 。

バイオロジカルパルプ化は植物組織の腐朽, 腐敗と 極めて密接な関連性を持っている。パルプ原料が木材, すなわちグリノセルロース系資源の場合には，担子菌， 特に白色腐朽菌が中心であり, そのなかでも Phanerochaete chrysosporium (Sporotorichum purverulentum), Coriolus hirstus, Corprinus cinereus が広く取
上げられている3）。非木材，特に靶皮纎維を中心とする ペクトセルロース資源の場合のバイオロジカルパルプ 化は, 発酵精練又は腐化精練 (retting) との呼称で, 種々の糸状菌, 細菌が提案されている ${ }^{4) 566}$ 。ここで注意 しなければならないことは, バイオロジカルパルプ化 に関与している腐朽菌は，いずれも死物寄生菌である ということである。

筆者らは, 靶皮纎維の生化学パルプ化の研究過程で 絾維植物の植物病の病徴がバイオロジカルパルプ化現 象に極めて類似性があることに着目し, 桑枝, コウゾ などの軟腐病の病原細菌である Erwinia carotovora を取上げて研究してきた7)。つまり，活物寄生菌を生化 学パルプ化に応用してきた点に特徵がある。

一般的にいって, 植物の柔組織病を起す細菌にはぺ 
クチン分解能を持つものが多い。しかし，植物に対す る病原性とペクチン分解性とは必ずしも一致していず, まして，パルプ化能との関係は明かでなかった。

本稿では, E. carotovora の生産するぺクチン分解酵 素系による生化学パルプ化における機構的考察を植物 病原性と関連づけて考察してみたい。

\section{2. マセレーションと生化学パルプ化の差異}

植物病理学をはじめ農芸化学の分野で広く使用され ている術語の一つにマセレーション (maceration) が ある。「解離」,「離解」,「単離」あるいは「分散」など と訳されている。筆者らは, 本稿のような場合には「軟 化」との訳が適していると思う。ペクチンを多量に含 んだ植物柔組織を構成している細胞間結合を弱めて単 一細胞に分離する処理のことであり，細胞壁あるいは 中間層のペクチン質のゲルをゾル化する現象である。 この処理には機械的, 超音波, 酸, アルカリ, キレー ト化剛, あるいはペクチン分解酵素などが使用されて いる。

木材化学, 製紙科学の分野でマーセリゼーション (マーセル化, marcerization) というよく発音の似た 術語があるが, これは全く別概念である。因みに, マー セル化とは，七ルロース纎維を 17-18\%の苛性ソーダ 液に浸漬し，アルカリセルロースを生成する操作であ り, シルケット加工の方法である。

ところで, パルプ化というのは, 単に細胞間を埋め る中間層のみならず, 一次壁, 二次壁のセルロース緎 維膠着物も化学的又は機械的に解離させてセルロース 絾維を単一の繊維として抽出することである。マセ レーションと対比してみると分るように，パルプ化の 場合には細胞壁の崩壊を伴なう。従って, パルプ化は マセレーションよりも植物組織の崩壊が一歩進んだ状 態であるということができる4)。ただ, 便宜的にはほぼ 同一の意味で使用している傾向があり，本稿でもそれ に準じている。

\section{3. 生化学パルプ化機構研究の端緒}

古くは, マセレーションを起す酵素として, プロト ペクチナーゼ (protopectinase) という酵素が存在する と考えられていた。この酵素は不溶性のプロトペクチ ンを可溶性のペクチンに転換する酵素である。また, これとは別にマセレーション酵素 (maceration enzyme 又は macerating enzyme) という特殊な酵素系

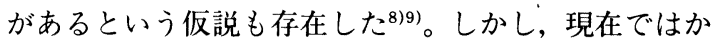
かる特殊な酵素の存在を考える必要はないとされてい る。マセレーションの主要な役割をしている酵素はぺ
クチン分解酵素系のうちで, ペクチンの主鎖， $\alpha-1,4$ ーグリコシド結合をランダムに切断する酵素, すなわち endo-ポリガラクチュロナーゼ (endo-polygalacturonase, 略して endo-PG と記す) 又は endo-ペクチン 酸リアーゼ (endo-pectate lyase 又は endo-pectate trans-eliminase, ここでは endo-PATE と略記)ない し endo-ペクチンリアーゼ (endo-pectin lyase 又は endo-pectin trans-eliminase, endo-PNTE と略記) であるとされた。

Erwinia 属細菌の場合, 主要なぺクチン分解酵素は endo-PATE であり，まず生化学パルプ化に適した同 属細菌のクリーニングの目的で, 国内外の軟腐病研究 者から集めた 72 株の Erwinia 属細菌（E. carotovora 62 株; E. chrysanthemi 9 株; E. herbicola 1 株) につ いて, 標準培養法を定めて培養し, endo-PATEの分 泌量と不飽和ガラクチュロン酸量又は結束繊維率との 相関性を求めた ${ }^{10)}$ 。その1例を図 1 に示す。endo -PATEの生成量と結束纎維率との相関性は認められ るものの大きなバラツキがあり, かつ, E. carotovora と比較するとE. chrysanthemi が同一endo-PATE 量でも極端に解繊率が低いことが分かる。

これらの結果を説明する機構として, 筆者は植物病 理学のマセレーション機構の諸説を整理して 3 つの仮 説を立てた。第 1 は, E. chrysanthemi が生成する

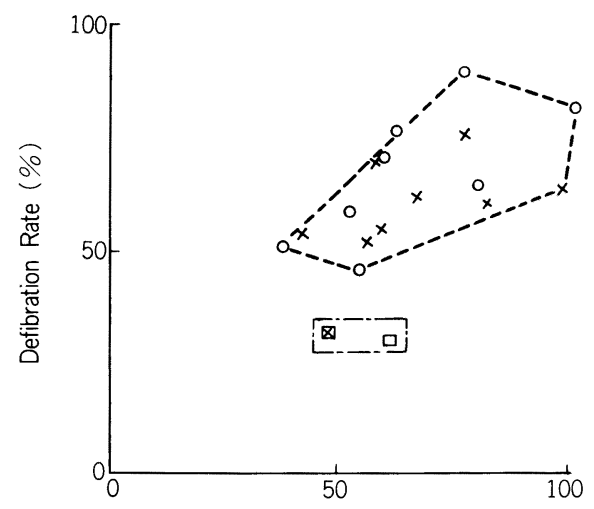

PAL Productivity ( unit $/ \mathrm{m} l$ )

Fig.1 Relationship between PAL productivity of E. carotovora and E. chrysanthemi strains and defibration rate in enzymatic pulping of kozo bast.

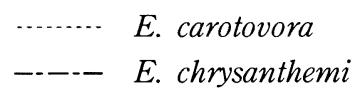

$\times$ Pulping by a constant volume

$\bigcirc \quad \square$ Pulping by a constant PAL unit 
endo-PATE は勒皮繊維のパルプ化には活性の低いイ ソ酵素であるという考え方である。Garibaldi ら ${ }^{11)}$ よると同じ PATEでもニンジン, ジャガイモ, キウリ の組織を容易にマセレーションするもの，ニンジンに はマセレーションの作用が弱いがジャガイモとキウリ には強いもの, 3 つの植物組織に対して全くマセレー ション作用のないものがあると報告がある。類例は Coniothyrium diplodiella, Botrytis cinerea, Clostridium felsineum などにもみられる。主鎖を分解する ペクチン分解酵素にイソ酵素が存在し，そのなかには マセレーション活性を持なないものも存在するという 考え方である9

第 2 の説は石井 ${ }^{12)}$ が Aspergillus japonicus で提唱 しているマセレーション因子という説である。それ自 身はマセレーション作用を持たない蛋白質で, endo -PG endo-PATE と共存するとジャガイモなどを マセレーションする作用がある。このマセレーション を相補する因子をマセレーション因子と名付けている。 この因子はペクチン, ペクチン酸, アラビナン, ガラ クタン, キシラン, 蛋白質などの分解能はなく, ある のはセルロース分解性のみであるが，それも微弱であ る。このように, 主鎖を切断する endo-PG, endo -PATEの働きとそれ等を強化する非酵素的な因子と の合奏作用という考え方である。

第 3 の説は endo-PG, endo-PATE を補強するもの は中性糖やウロン酸を放出するある種のへミセルラー ゼであるとするものである。これらの考え方は

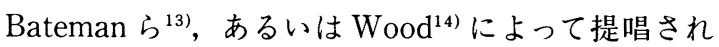
ているが, 特に具体的な例示があるわけではない。植 物柔組織の成分組成からの推測である。

このような諸説に関連し, E. carotovora の生産する 酵素による靶皮纎維の酵素パルプ化においてはどのよ
うな機構で進行しているのであろうか。

\section{4. イソ酵素とマセレーション因子の探索}

\section{1 ペクチン酸リアーゼの pI-イソ酵素}

E. carotovora FERM P-7579の生産する endo -PATE をイオン交換クロマトグラフィー, ゲル濾過, 等電点電気泳動で精製を試みたところ, 同じペクチン 酸リアーゼ活性を有する 4 種類の酵素に単離された ${ }^{15)}$ 。 その基本的性質は表 1 のようであるが，それを正確に はイソ酵素であるとすることは出来ない。イソ酵素と 同定されるためには, (1)本質的に同一の触媒反応を行 う酵素が 2 種以上あり，(2)蛋白質の一次構造が異なり， かつ, (3)異なる遺伝子によって決定されていなければ ならないからである。ここでは, (2)及び(3)の研究が十 分になされていなかったので, 等電点の相違なる同一 触媒反応活性のある酵素として, $\mathrm{pI}$-イソ酵素と命名し ている。注目される特性は, 等電点が 10.0-10.9 と極 めて高く, かつ, 至適 $\mathrm{pH} も 9.3 \sim 9.7$ とアルカリ側に あることである。endo-PATEは系状菌, 例えば $A$.

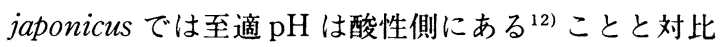
すると興味がある。

endo-PATE は細菌から生産されるものは好アルカ リ性酵素なのである。これらの $\mathrm{pI}$-イソ酵素はマセ レーション活性では差異はなく, 第 1 の説は否定的と なった。

また, 同じE. carotovora でも菌株が異なれば, $\mathrm{pI}-$ イ ソ酵素の分布が異なることが明らかにされた ${ }^{16)}$ 。同属 同種の FERM P-7576 株は, 図 2 のように pI-イソ酵 素は 2 種であり，一遺伝子・一酵素説に従えば，この 菌株は前述の FERM P-7579 株の pI-イソ酶素を生産 する遺伝子が部分的に欠如していたり，あるいは欠陷 を持っていると考えられる。

Table 1 Fundamental Properties of endo-PATE pI-Isozymes

\begin{tabular}{lcccc}
\hline \multicolumn{1}{c}{ PATE pI-isozyme } & I & II & III & IV \\
\hline Molecular weight & 28,000 & 31,000 & 28,000 & 33,000 \\
Isoelectric point & 10.0 & 10.6 & 10.3 & 10.9 \\
Optimum pH & 9.7 & 9.3 & 9.7 & 9.5 \\
Optimum Ca & 0.6 & 0.5 & 0.6 & 0.6 \\
$\mathrm{~km}_{\mathrm{m}}(\mathrm{wt} \%)$ & 0.054 & 0.050 & 0.052 & 0.055 \\
$V_{\max }\left(\mathrm{mmol} \mathrm{mg}^{-1} \mathrm{~min}^{-1}\right)$ & 0.70 & 0.69 & 0.78 & 0.80 \\
Comparison ratio $^{a}$ & 3.77 & 3.95 & 3.60 & 3.90 \\
\hline
\end{tabular}

a Comparison ratio $=\frac{\Delta \text { fluidity }\left(1 / \eta_{\mathrm{sp}}\right) / \text { time }}{\Delta \mu \mathrm{mol} \text { reducing groups } / \text { time }}$ 


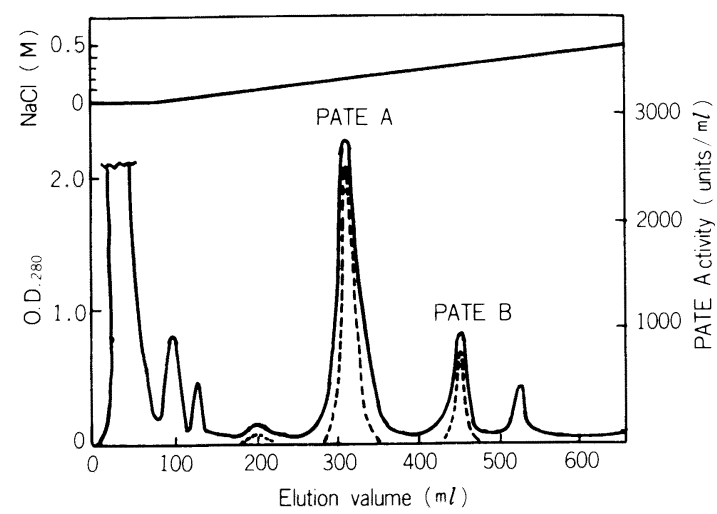

Fig.2 Chromatography of Crude Enzyme from FERM P-7576 on CM-Sepharose CL-6 B. The crude enzyme (480.5 mg as protein) was applied on a column of CM-Sepharose $\mathrm{CL}-6 \mathrm{~B}$ (column size : $1.6 \times 30 \mathrm{~cm}$ ), previously equilibrated with $10 \mathrm{mM}$ sodium phosphate buffer ( $\mathrm{pH}$ 6.0). The charged column was developed with a gradient of $0.5 \mathrm{M} \mathrm{NaCl}$ in the same buffer at a flow rate of $20 \mathrm{ml} / \mathrm{hr}$.

—, O. D.280 …, PATE activity.

\section{2 マセレーション因子}

endo-PATE 以外にパルプ化に関与する要因が存在 することは, endo-PATE とパルプ中の結束繊維率と が十分な相関が得られないことから明らかである。そ のうち, マセレーション活性に差異のある endo -PATEのイソ酵素ではないことが解明された。そこ で endo-PATE 以外のマセレーション活性を持つ蛋 白質の分離を試みた。

精製手段としては, カチオン交換クロマトグラ フィー, DEAE-セファローズ CL-6 B 及びセファクリ ル S-200のカラム, 更に焦点電気泳動を 2 回行って, マセレーション活性を持つ単一の蛋白質を分離した ${ }^{17)}$ 。 このものは Link ペクチンをトランス脱離する以外は 特別の触媒反応を示さないことから, endo-PNTEと 同定された。単離された endo-PNTE の特性は表 2 に 示す通りである。これによって, E. carotovora はマセ レーション活性を持つ 2 種のペクチン分解酵素, endo -PATE 及び endo-PNTEを同時に分必することが 明らかにされた。その酵素活性の比率は $34: 1$ であっ た。

高橋らの研究 ${ }^{18), 19)}$ によると, マイトマイシンC など の抗生物質のように DNA 合成を阻害するような.もの
Table 2 Fundamental Properties of endo-PNTE Spontaneously Secreted by E. carotovora FERM P-7576

\begin{tabular}{|c|c|}
\hline Molecular weight & 39,000 \\
\hline $\mathrm{pI}$ & 8.2 \\
\hline Optimal pH & 9.3 \\
\hline $\mathrm{Km}(\mathrm{wt} \%)$ & 0.045 \\
\hline $\mathrm{V}_{\max }\left(\mathrm{mmol} \mathrm{mg}^{-1} \mathrm{~min}^{-1}\right)$ & 1.08 \\
\hline Comparision ratio $\quad \therefore$ & 4.15 \\
\hline
\end{tabular}

を共存させて培養すると, E. carotovora は endo -PATEの生産から endo-PNTE の生産に切替える。 この研究に基づいて, 露無ら ${ }^{20)}$ は同菌が endo-PATE と endo-PNTEの両ペクチン分解酵素を生産するの は, 培養に用いる植物組織のなかに DNA 合成阻害物 質が存在しているからではないかという仮説を提示し た。同菌株から endo-PNTE の生産が DNA 合成阻害 物質に起因するとすれば，筆者らの研究時にendo -PNTE が単離されたのは培地に用いた炭素源がシト ラスペクチンであり, そのなかにかかる阻害物質が存 在していたと考えられるのである。しかし，炭素源と して合成品であるグリセロールを用いても endo -PNTE は, その混合比率は低下しているものの, 明ら かに生成を見る。従って, endo-PNTEの生産をすべ て DNA 合成阻害要因に帰するという考え方 ${ }^{20)}$ とは 矛盾があり今後更に研究を行う必要があると思われる。

ところで, 生化学パルプ化が endo-PATE と endo -PNTEの合奏反応として起るとすると, この両者の 混合割合に最適混合割合があるに違いない。これら 2 種の $\mathrm{pI}$-イソ酵素は一まとめにして, 両者の最適の混 合比率を生化学パルプ化のパラメータを基準に測定し た21)。その結果は図 3 に示すように, endo-PATE：

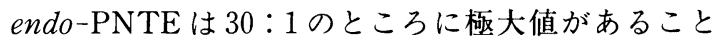

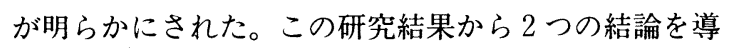
くことができる。第 1 には, 生化学パルプ化, あるい はマセレーションは主として endo-PATEが主役を

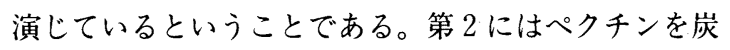
素源とした培養のときに得られた混合比は最適混合比 率に近い值となっているということができることであ る。つまり, 通常の混合比は, 最も大きいマセレーショ ン効果を持つという搨理に注目しなければならないの である。

この 2 種類のペクチン分解酵素系でマセレーション が遂行されると説明した場合, 図 1 に示したように, E. chrysanthemi では endo-PATE を基準とした時に 


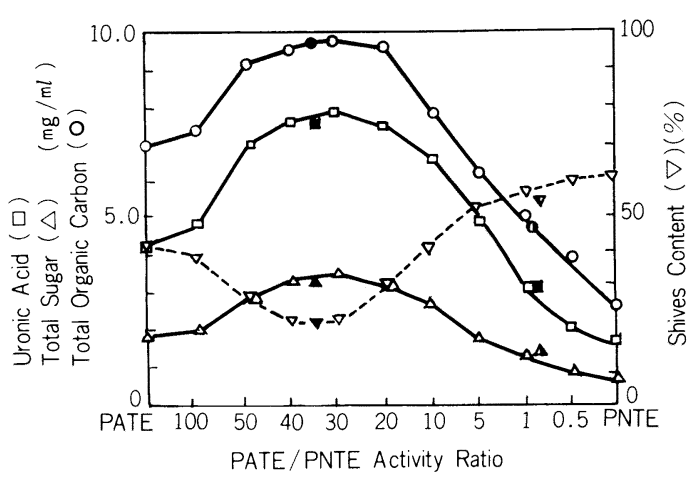

Fig.3 Optimal Constitution of PATE and PNTE for Maceration of Caustic Soda -presoaked Mitsumata Bast.

Caustic soda $(1 \% \mathrm{NaOH})$-presoaked mitsumata bast ( $20 \mathrm{~g}$, dry weight) was pulped with the crude enzyme produced by E. carotovora FERM P-7576 with $(\square$, $\boldsymbol{\Lambda}, \boldsymbol{C}$ and $\Delta$ ) or without $(\boldsymbol{\square}, \boldsymbol{\Delta}, \boldsymbol{\bigcirc}$ and $\boldsymbol{\nabla})$ the addition of mitomycin $\mathrm{C}$. Simultaneously the same procedure was performed with the purified enzyme composite of endo-PATE and endo-PNTE at an appropriate mixing ratio $(\square, \triangle, \bigcirc$ and $\nabla)$. The total enzyme activity of endo -PATE and endo-PNTE in each enzyme preparation was adjusted to 800 units. The enzyme reaction was performed in $200 \mathrm{~m} l$ of $0.1 \mathrm{M} \mathrm{NH}_{4} \mathrm{OH}-\mathrm{NH}_{4} \mathrm{Cl}$ buffer $\left(\mathrm{pH} \mathrm{9.5)}\right.$ with rotary shaking at $30^{\circ} \mathrm{C}$ for $6 \mathrm{hr}$.

マセレーション作用が低下している(10)のは何故かと いう疑問が生まれる。そこで, 同種の endo-PNTE を 検討してみると，E. carotovoraのそれと異なり, $\mathrm{pI}$ は 酸性側にあることが分った ${ }^{22)}$ 。しかもこの endo -PNTEはE. carotovoraのそれと比較するとマセ レーション活性も劣る。E. carotovoraでは endo -PATE は通常 $\mathrm{Ca}^{2+}$ などの金属イオンの添加でペク チン分解性は向上する15)のであるが, プロトペクチン を対象としたときは殁んど添加効果はなく, 逆に負の 効果を持つ ${ }^{23)}$ 。そのことは E. chrysanthemi の精製 endo-PATEの場合も同様である ${ }^{22)}$ 。しかしながら,こ の系の endo-PNTEは $\mathrm{Ca}^{2+}$ の添加効果はマセレー ションで著しく正の効果を示した。これらの実験効果 から, E. chrysanthemiの endo-PNTE はカルボキシ ル基等の負イオンの多い蛋白質であり, ペクチン質と
静電反撥などで相互作用が起り難いのではないかと考 えられる。C $\mathrm{Ca}^{2+}$ などの正電荷を持つイオンの添加は, それらを中和し相互接近, 相互作用が起りやすい環境 を整える役割を果しているのではないかと推定される。 つまり,E. chrysanthemiのマセレーション活性が低 い理由は, 補助作用をしている endo-PNTE の機能が 低いことによるものであり，それをE. carotovora の endo-PATE と置換すれば活性は E. carotovora 並み になるのである22)。これらの結果は, endo-PNTE は マセレーションの補助機能ではあるが, 良好な活性を 示すには極めて重要な役割を持っているということが できる。

以上の結果から，ペクトセルロース系から成る靶皮 繊維のマセレーションにおいては, endo-PATE と endo-PNTE が合奏的に作用していることを明らか にした。

そこで, もう一度, 本研究の出発点になったペクチ ン分解酵素の活性と解繊率との相関性を調べてみた。 マセレーションに関与しているペクチン分解酵素は, endo-PATE と endo-PNTEであるから, この両者の 和をパラメーとして，解緎率をプロットすると図 4 の

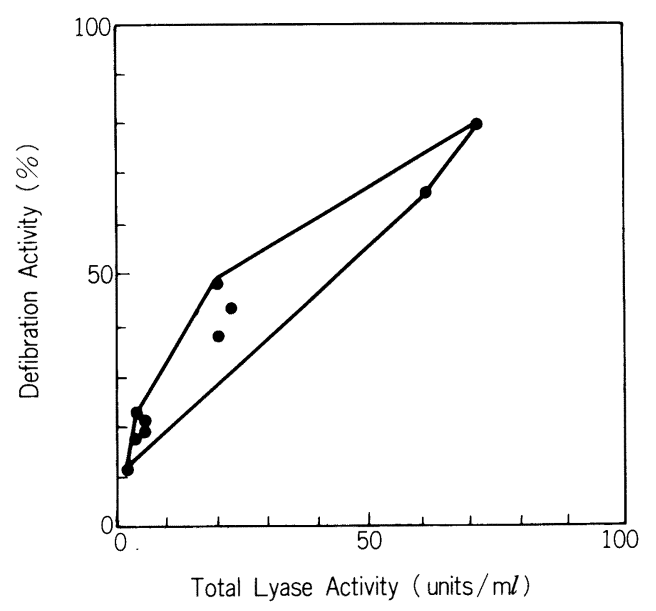

Fig.4 Relationship between defibration activity and total lyase activity of crude enzyme from Erwinia strains. Defibration activities of crude enzymes produced by 10 -arbitrary strains of Erwinia spp. toward mitsumata bast were given as a function of the sum activity of endo-PATE and endo-PNTE of each crude enzyme. The data were displayed in a group. 
ようになり，ほぼ直線的に近い関係に修正されること が分った24)。

\section{3 菌体外へのペクチン分解醍素の分泌性}

同じE. carotovora に属しながら, マセレーション 因子となる endo-PATE 及び endo-PNTE を生産す る能力にかなり差があることが明らかにされている。 この差異を生じている原因は 2 つ考えられる。第 1 は 生産性そのものが不活発, つまり菌株の活動性が低い こと, 第 2 には生産性そのものは高いのであるが菌体 外への放出性が低いこと, 換言すれば細胞壁を構成す る層を透過できないことである。後者においては，菌 体内酵素の蓄積は高いと考えられるのである。

ペクチン分解酵素の細菌細胞内での生成機構は Slack らの説 ${ }^{25)} に$ 従えば, 図5のようである。更に細 分すれば細胞壁のどの部分が通過のボトルネックに なっているかである. E. carotovora はグラム陰性菌に 属するが，この菌群の細胞壁は 3 層から成立っている。 内膜, その外側にあるぺプチドグリカン層（すなわち, ペリプラズム) 及び最外部の外膜である。筆者らの研 究結果では, 分泌性の低い菌株は, endo-PATE がぺ リプラズムの部分を通過できず，内部に蓄積されてい ることが分った ${ }^{26)}$ ここの層に存在する酵素をペリプラ ズム酵素と呼ぶが，一般に加水分解型の酵素が多い。 この種の酵素は浸透圧ショックなどで菌体外に取出せ ることが知られているが, endo-PATEについては未 検討である。

\section{5. 織維マトリックスの分解機序}

\section{1 アルカリ前浸漬に伴なう効果}

靶皮中のペクチンは，(1)鞁皮繊維束とそれを取り巻 く柔軟組織との間, (2)柔軟組織中で細胞の間に中間層 として, (3)靶皮維管束中で繊維の間に中間層として,

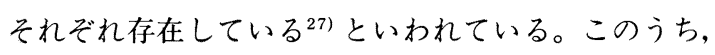
(1)及び(2)のペクチンは弱アルカリで除去できるが, (3) はペクチン質がリグニン化して抵抗性が強く, 溶解す るのは難しいといわれている。

筆者らは, 酵素パル化に先立って, アルカリ前浸漬 が効果的であることを明らかにした ${ }^{28)}$ 。その効果とし ては，上記の(1)及び(2)のような弱アルカリ溶出成分の 除去及び繊維マトリックスの膨潤効果であると推定さ れるが, 詳細な理由は明らかにされていなかった。

そこで, アルカリ前浸漬により何が除去され, 繊維 原料側にはどんな成分が存在しているのかを分析して みた ${ }^{29)}$ 。その結果を図 6 に示す。水， $0.1 \% \mathrm{NaOH}$, $1.0 \% \mathrm{NaOH}$ 及びこれら希薄アルカリ水溶液に浸漬 後, endo-PATE と endo-PNTEの混合系で処理した 結果をまとめたものである。注目されることは, アル カリ前浸漬やそれと併用して酵素処理することでリグ ニン成分が溶出して ${ }^{30}$, 繊維中のリグニン, 特に可溶性 リグニンが低減しているという現象である ${ }^{29)}$ 。そこで, ここで溶出されているリグニン成分をゲル濾過及び疎 水クロマトグラフィーで分析を試みた。ゲル濾過では

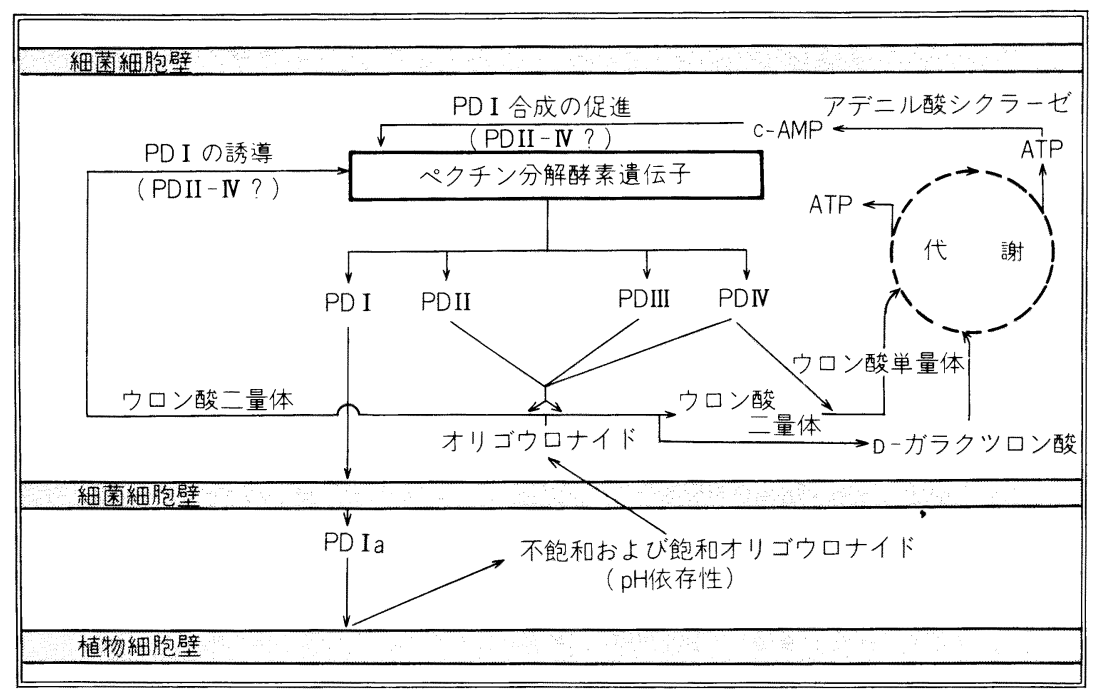

Fig.5 Schematic interaction of plant cell wall and pectinolytic enzymes from E. carotovora $\mathrm{PD}$ : pectate depolymerase

(後藤正夫著「新植物細菌病学」から引用) 


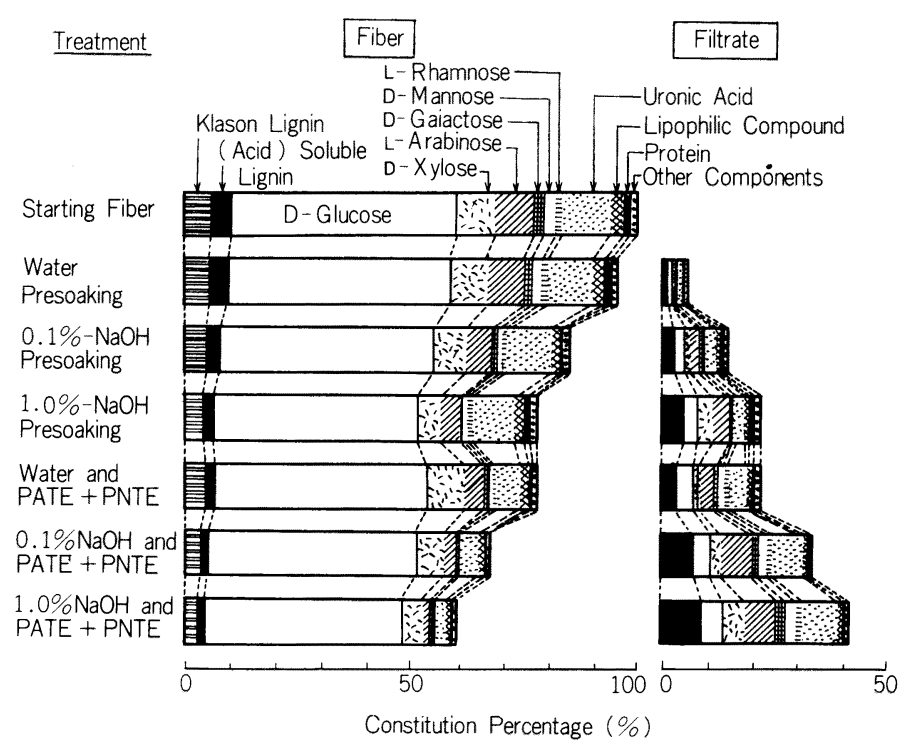

Fig.6 Solubility behaviors of fiber components in presoaking and in enzymatic pulping.

$\mathrm{A}, \mathrm{B}$ 及び Cの 3 成分に分離し，分子量はそれぞれ 25,000，20,000-25,000 及び 20,000-25,000 ダルトン と推定され, 更に疎水クロマトグラフィーでは $\mathrm{B}, \mathrm{C}$ は それぞれ 2 成分に分離した。これらのリグニン成分は 表 3 のように中性糖が結合されている。従って，この リグニン成分はリグニン・多糖結合体 (lignin-carbohydrate complex, 以下 LCC と略称) で溶出されてく ることが明らかにされた。靶皮部は木化があまり進ん でいず，比較的低分子の LCC が溶出されることは大 変興味あることである。また, ペクチン質のマトリッ クスを分解すれば, リグニンも除去されるという定性 的な結果が明確に裏付けられた。

Table 3 Carbohydrate composition of LCC fractions

\begin{tabular}{|c|c|c|c|c|c|c|c|}
\hline \multirow{2}{*}{ LCC } & \multicolumn{6}{|c|}{ Neutral sugars ${ }^{a}(\%)$} & \multirow{2}{*}{$\begin{array}{l}\text { Molecular } \\
\text { weight }\end{array}$} \\
\hline & Ara & Gal & Rha & $\mathrm{Xyl}$ & Glu & Man & \\
\hline$A-1$ & 64.1 & 33.2 & 1.1 & 0.9 & 0.4 & 0.3 & 25,000 \\
\hline B-1 & 65.8 & 31.5 & 0.9 & 1.0 & 0.5 & 0.3 & 25,000 \\
\hline B-2 & 24.0 & 14.0 & 0.4 & 60.4 & 0.6 & 0.6 & 20,000 \\
\hline$C-1$ & 68.8 & 28.4 & 0.8 & 1.1 & 0.5 & 0.4 & 25,000 \\
\hline$C-2$ & 19.7 & 8.4 & 0.2 & 71.5 & 0.1 & 0.1 & 20,000 \\
\hline
\end{tabular}

a) Ara $: L_{\text {-arabinose }}$ Gal:D-galactose Rha : L-rhamnose Xyl : $D^{-x y l o s e}$ Glu : D-glucose

Man : D-mannose
同時に, 繊維マトリックスがアルカリ液によって膨 潤するという定性的な性質も, 図7のようにScallan らの方法で定量性を持たせることができた。アルカリ 環境下で, 膨閏した繊維マトリックスに endo-PATE 及び endo-PNTE が入り込み, マセレーションを行う わけであるが,そのアクセシビリティは高く,パルプ化 の速度が大きいという結果が裹打ちされたわけである。

\section{2. ペクチン質は LCC との会合性}

靶皮繊維中でリグニン質は LCC の形で存在してい

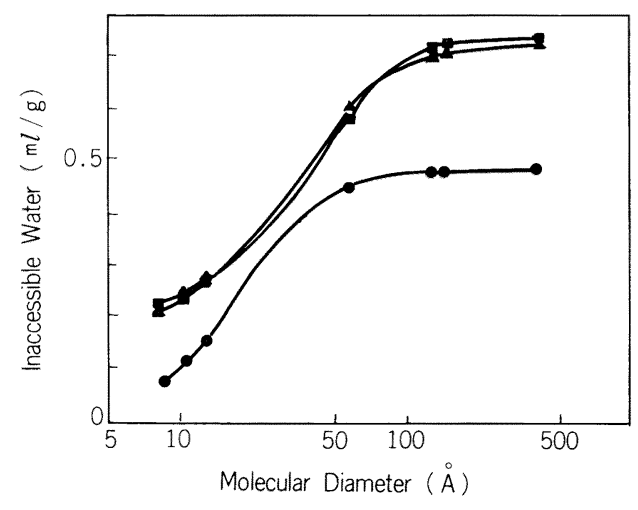

Fig.7 Effect of presoaking on inaccessible water amount of bast fibers.

: water presoaking

А : $0.1 \%-\mathrm{NaOH}$ presoaking

口 : $1.0 \%-\mathrm{NaOH}$ presoaking 
ることが明らかになったが，ペクチン質とはどのよう な関係にあるかは明らかでない。そこで，生化学パル プ化過程でペクチン質，リグニン質(すなわち， LCC) の溶質がどのように变化するかをミッマタ白皮で追跡 した ${ }^{31)}$ 。ゲル濾過で経時的に追跡すると，12 時間の反 応でペクチン成分と LCC 成分がほぼゲル濾過で分離 できることが分った。そこで, 䤃素パルプ化を精製し たendo-PATEのみで行い，そこで生成してきたぺク チン質と LCC をゲル濾過, アニオン交換樹脂, フェニ ルセファロースの疎水クロマトグラフィーで分離した。 その時の成分を LCC では A-2-1, ペクチン質では A -1-1 及び A-3-1 と名づけた。同様に endo-PNTEの みで酵素パルプ化した溶出成分中, LCC は N-2-2, ペ クチン質は N-1-1, N-3-1 と記号をつけた。これらの 成分中の中性糖を分析して見ると, 表 4 のようになっ た。結果をみると endo-PATE で溶出してくる LCC の中性糖は L-アラビノースとD-ガラクトースが主体 でその構成は $2: 1$ であり,それ以外の糖は殆んど含ま れていない。他方 endo-PNTEで溶出してくる LCC の中性糖は D-キシロースが $70 \%$ を占め, 残りを $\mathrm{L}-ア$ ラビノースと D-ガラクトースが分けあっている。この 傾向はぺクチン質のなかの中性糖の構成でも類似の傾 向を持っている。

この実験結果はへミセルロースの生合成過程 ${ }^{22)}$ と 重畳させると極めて重要な推測がなされる。細胞壁の へミセルロースの分布については完全に一致してはい ないが, 細胞壁形成の初期では中間層 (M) と一次壁 (P) でL-アラビノースと D-ガラクトースを多く含む 多糖が堆積される。この中間層及び一次壁の形成過程 ではウリジン-5'-二リン酸 (UDP) -グルクロン酸から
エピメラーゼによりUDP-ガラクチュロン酸が生じ, シンテターゼによりペクチンが生成するとされている。 endo-PATE で分解されて溶出してくるのは, 構成糖 の組成からみるとこの画分に由来するのではないかと 推定させる。二次壁 $\left(\mathrm{S}_{1}+\mathrm{S}_{2}+\mathrm{S}_{3}\right)$ のへミセルロース の堆積は一次壁が形成がなされてから行われるのであ るが,これはUDP-グルクロン酸の脱炭酸によって生 成するUDP-キシロースからキシランを生成するシン テターゼによって行われる。このシンテターゼは二次 壁の肥厚が始まると活性化し，逆にペクチン合成酵素 の活性は急速に低下するのである。つまり，二次壁に はキシランが多く堆積しているのである。endo -PNTEで分解されて溶出してくるものは, この画分 に由来しているように思える。この推測が正しいもの とすれば， $\mathrm{M}+\mathrm{P}$ 層に堆積するぺクチン質はエステル 化度が低く，S 層に堆積されるそれは高度にエステル 化されていることを予測させる。これらの推測の正否 は今後の研究に待たねばならない。

\section{3 キシランマトリックスの分解処理}

キシラン成分は二次壁に堆積し, この画分の分解は ペクチン分解酵素のみでは必ずしも十分でないかもし れない。逆にキシラナーゼで予じめこのキシラン成分 を分解させれば，生化学パルプ化は高度に進行すると 推定される。そこで，予じめキシラナーゼでミッマ夕 白皮を処理した後, ペクチン分解酵素でパルプ化する と，パルプ化は顕著に促進されることが明らかにされ た ${ }^{33)}$ 。キシラナーゼは E. carotovora も生産しており, 従って, $\mathrm{pH}$ を微酸性〜中性に保持すれば起源の異な るキシラナーゼを添加しなくても作用させることがで きる。留意すべきことは，キシラナーゼのみでは全く

Table 4 Carbohydrate composition of enzymatically eluted LCCs and pectic fragments

\begin{tabular}{|c|c|c|c|c|c|c|c|}
\hline \multirow{2}{*}{ Fraction } & \multicolumn{6}{|c|}{ Neutral sugarsa) $(\%)$} & \multirow{2}{*}{$\begin{array}{l}\text { Molecular } \\
\text { weight } \\
\quad\left(\times 10^{3}\right)\end{array}$} \\
\hline & Ara & Gal & Rha & Xyl & Glu & Man & \\
\hline \multicolumn{8}{|l|}{$(\mathrm{LCC})$} \\
\hline$A-2-1$ & 63.4 & 33.8 & 1.0 & 1.1 & 0.3 & 0.4 & 25 \\
\hline $\mathrm{N}-2-1$ & 67.8 & 30.7 & 0.6 & 0.8 & 0.5 & 0.6 & 25 \\
\hline $\mathrm{N}-2-2$ & 18.6 & 17.9 & 0.5 & 72.3 & 0.4 & 0.3 & 20 \\
\hline \multicolumn{8}{|c|}{ (Pectic fragment) } \\
\hline A-1-1 & 63.4 & 25.5 & 9.4 & 1.7 & 0 & 0 & $\geqq 100$ \\
\hline$A-3-1$ & 62.4 & 26.2 & 9.9 & 1.5 & 0 & 0 & 8 \\
\hline $\mathrm{N}-1-1$ & 14.0 & 18.4 & 8.7 & 68.9 & 0 & 0 & $\geqq 100$ \\
\hline $\mathrm{N}-3-1$ & 13.7 & 8.9 & 6.1 & 74.3 & 0 & 0 & 10 \\
\hline
\end{tabular}

a) Ara $:$ L-arabinose Gal $: D^{-}$galactose Rha $:$L-rhamnose Xyl : $\mathrm{D}^{-}$xylose Glu : D $^{-}$glucose Man : $\mathrm{D}^{-}$mannose 
マセレーション効果は認められない点である。

\section{6. おわりに}

靶皮繊維の生化学パルプ化について, 主として機構 的な面について筆者らの研究成果を中心に概説した。 この機構解明の端緒は, endo-PATEの活性と解繊率 との関係が分散して, 一次の関係が得られなかったこ とにある。小さな疑問をもって, 解明を加えていくう ちに, マセレーションの機構の本質に触れるような成 果となり, それは植物病, 特に軟腐病の発生機序にも 示唆的な成果となったと思われる。今後のバイオテク ノロジーの進展は, この分野の研究にも大きく寄与す るものと考えられる。

\section{引用文献}

1）小林良生；紙パ技協誌，37（1)，40（1983）

2) 小林良生; “バイオ新素材”, pp.267-273 (1987) シー・エム・シー社 (東京)

3）西田篤実; 繊維学会誌，43 (8), P-313 (1987)

4）小林良生; 纎維学会誌, 33 (1), P-317 (1977)

5）中浜敏雄; “繊維原料の醴酵精練に関する基礎的 研究とその工業化” (京都府立大農学部応用菌学研 究室) (1965)

6）朝井勇宣，斉藤日向；醴酵協会誌，10，22(1951)

7）工業技術院四国工業技術試験所編，“重要地域技術 研究開発, 非木材資源の生化学パルプ化技術”, pp.4-53（1987），工業技術院総務部計画課・四国 工業技術試験所

8) J. J. Doesburg; "Pectic Substances in Fresh and Preserved Fruits and Vegetables", pp.74-75, (1965) Institute for Research on Storage and Processing of Horticultural Produce, Wageningen, The Netherlands.

9）梶 明；化学と生物，40，409（1966）

10）小林良生, 小前幸三, 田辺寛之, 松尾隆吉;

a) "A Comment on Maceration Mechanism in Enzymatic Pulping of Bast Fiber by Alkalophilic Pectinolytic Enzymes Produced by Genus Erwinia" , Biotechnology in the Pulp and Paper Industry, London, September 12 -14, (1983) pp.79-88.

b) Biotechnology Advances, 投稿中.

11) A. Garibaldi and D. F. Bateman ; Physiol. Plant Path., 1, 25 (1971)

12) S. Ishii and K. Kiho; Phytopathol., 66, 1077. (1976)
13) a) D. F. Bateman, R. L. Millar; Ann, Rev. Phytopathol, 4, 119 (1966)

b) D. F. Bateman: Neth. J. Plant Pathol., 14 (Suppl. 1) , 67 (1968)

14) R. K. S. Wood; Ann, Rev. Phytopathol. 11. 299 (1960)

15）田辺寞之, 小林良生, 松尾雄志, 西 望, 和田文 雄; Agric. Biol. Chem., 48 (8) , 2113 (1984)

16）田辺寛之, 松尾隆吉, 小林良生; Agric. Biol. Chem., 49 (12) , 3595 (1985)

17）田辺寞之, 小林良生；Agric. Biol. Chem., 50(11), 2779 (1986)

18) S. Kamimiya, K. Izaki and H. Takahashi ; Agric. Biol. Chem., 36, 2367 (1972)

19) S. Kamimiya, T. Nishiya, K. Izaki, H. Takahashi ; Agric. Biol. Chem., 44, 1071 (1972)

20) S. Tsuyumu, T. Funakubo, K. Hori, Y. Takikawa and M. Goto ; Ann. Phytopath. Soc., Jpn., 51, 294 (1985)

21）田辺寞之, 小林良生, 伏見 豊, 金崎宽次, 多田 秀; Agric. Biol. Chem., 51 (2) , 589 (1987)

22）田辺寛之，小林良生；Agric. Biol. Chem., 51 (3), 779 (1987)

23）小林良生, 松尾隆吉, 福岡 聡, 浜田 康, 大川 昭典, 江㴊栄貫; 第 52 回紙パルプ研究発表会要旨 集, pp.14-17 (1985)

24）田辺寞之, 小林良生；Agric. Biol. Chem., 51(10), 2845 (1987)

25) J. P. Slack, M. S. Mount, P. M. Berman and J. P. Hubbard, Phytopathol., 70, 267 (1980)

26）田辺寞之, 小林良生; 昭和 62 年度農芸化学大会要 旨集 p.790 (1987)

27）大蔵省印刷局研究所編，“みつまた紙”, pp.77-77 (1959)

28）小林良生, 松尾隆吉, 浜田 康, 大川昭典, 江㴊 栄貫 : 木材学会誌, 30 (10)，848（1984）

29）田辺寞之，小林良生，Holzforschung, 41 (6)，395 (1987)

30）小林良生, 松尾隆吉, Cellulose Chem. Technol., 11, 487 (1977)

31）田辺寞之, 小林良生, Holzforschung, 42 （1），47 (1988)

32）寺島典二，木材学会誌，33 (8)，615 (1987,)

33）田辺寛之, 松尾隆吉, 小林良生, Holzforschung, 印 刷中 